the Declaration as a handy and convenient codification of the principles of law which they intend to apply. It is perhaps too much to say that the Declaration is thus a dead letter, but it is unfortunate, from the standpoint of certainty, that it cannot apply to the present war, and that the action of the belligerents will not be tested by an international court, judicially and impartially determining and applying its principles to the many and complicated cases which are sure to arise during present hostilities.

\title{
EGYPT A BRITISH PROTECTORATE
}

On December 17, 1914, the British press bureau made the following announcement:

His Britannic Majesty's Principal Secretary of State for Foreign Affairs give notice that, in view of the state of war arising out of the action of Turkey, Egypt is placed under the protection of his Majesty and will henceforth constitute a British Protectorate.

The suzerainty of Turkey over Egypt is thus terminated and his Majesty's Government will adopt all measures necessary for the defence of Egypt and the protection of its inhabitants and interests.

The King has been pleased to approve the appointment of Lieutenant-Colonel Sir Arthur Henry MeMahon, G. C. V. O., K. C. I. E., C. I. S., to be his Majesty's High Commissioner for Egypt. ${ }^{1}$

There are many reasons why Great Britain should desire to establish its control in Egypt, although it contents itself with the establishment of a protectorate, leaving Egypt to the Egyptians in so far as internal administration is concerned. One is that Egypt is on the highway to India, and as many years ago as 1844 Kinglake, in his brilliant and fascinating narrative of experience in the East, Eothen, prophesied that the sphinx would one day calmly look down upon the British firmly established in Egypt. This was before the Suez Canal, whose construction made it seem most essential to British statesmen to control Egypt. The acquisition of a majority share of stock in the canal by Disraeli in 1875 was a step toward control of Egypt, and the rebellion of Arabi Pasha in 1881, which led to the intervention of Great Britain, the suppression of the rebellion by force, and the occupation of the country made the realization of the prophecy merely a matter of time. It is true that Mr. Gladstone, on behalf of Great Britain, stated that British troops would be withdrawn when the country could safely be evacuated; but it was generally felt and understood that the occupation was likely to be permanent.

${ }^{1}$ See the London Gazette, Nos. 29,010, 29,011, 29,012. 
For the time being Great Britain contented itself with a diplomatic agent and consul general, selecting for this important post Lord Cromer, then Sir Evelyn Baring, in 1883, and through his successful administration order was brought out of chaos. His position was not different in title from that of any other diplomatic agent and consul general in Egypt. In fact he advised the Egyptian Government on all matters in which Great Britain felt itself to be interested, and the advice was equivalent to a command, as the late Khedive Amas Hilmai found when he dismissed his ministers, satisfactory to Lord Cromer but displeasing to himself. In the course of a few days the new ministry was dismissed, and it thus became evident that under the velvet glove there was an iron hand. When the disorganized state of Egyptian finances, due to the extravagance of Ismail Pasha, in whose reign the canal had been built, threatened the credit of the country, Great Britain and France in 1876 practically assumed a joint control of the finances of the distressed country, and Great Britain called upon France to intervene jointly in 1881 to put down the rebellion of Arabi Pasha. Owing to trouble with the Chambers, France was unable to do so and Great Britain acted alone. The desire of the French Government was to acquire Egypt for itself, or, if that were impossible, to prevent any other Power from acquiring it, in the hope that French influence might become in the course of time so marked as to make Egypt in fact, if not in law, a French dependency. Therefore the occupation of Egypt by Great Britain was peculiarly distasteful to the statesmen of the Third Republic. However, in 1904, Great Britain and France put an end to their outstanding differences by the convention of April 8 of that year, by the terms of which Great Britain was to have a free hand in Egypt, so far as France was concerned, and France was to have a free hand in Morocco, so far as Great Britain was concerned. This was a further step toward British annexation of Egypt, although events moved more rapidly in Morocco than in the land of the Pharaohs. As is well known, France established its protectorate in Morocco, notwithstanding the protest of Germany, in 1911, and Great Britain has taken advantage of the war with Turkey to break the slender tie which bound that country to the Ottoman Empire.

Without going into the history of Egypt and a discussion of its legal relations to Turkey, for which the reader is referred to the leading case of the Charkieh (L. R., 4 Admiralty and Ecclesiastical Courts, 59) decided in 1873 by Sir Robert Phillimore, it may be said that an Albanian adventurer, known as Mahomet Ali, established himself in Egypt with the 
consent of the Porte, and without the intervention of the European Powers he would have taken Constantinople and proclaimed himself Sultan of the Ottoman Empire. The Powers, however, intervened, the Empire was saved for the moment, Egypt was declared to be a tributary state with an hereditary ruler, termed the Khedive, in the family of Mahomet Ali. In law Egypt was thus a part of Turkey, although it was an autonomous, that is to say self-governing, community. In fact it was practically independent of Turkish control, and, while the legal relation existed after as before the British occupation in 1883, Egypt was from that date in fact, though not in law, a dependency of Great Britain. From and after December 17, 1914, Egypt has become, and probably will remain, a protected state of Great Britain, or in the rhetorical language of Kipling, of the "far flung Empire."

\section{ANNEXATION OF CYPRUS BY GREAT BRITAIN}

On November 5, 1914, the British Foreign Office published the following notice in the London Gazette: "Owing to hostile acts committed by Turkish forces under German officers, a state of war exists between Great Britain and Turkey as from today." At the same time Great Britain declared the conventions of June 4, July 1 , and August 14, 1878, between Great Britain and Turkey, by the terms of which Great Britain acquired the right to occupy and administer Cyprus, to be annulled by the war, and formally annexed Cyprus, as appears from the following extract from the Order in Council of November 5, 1914: "From and after the date hereof the said island shall be annexed to and form part of His Majesty's Dominions, and the said island is annexed accordingly."

It is common knowledge that Great Britain threatened, in 1878, to intervene in the Russo-Turkish war; that Great Britain objected strenuously to the terms of peace which Russia had dictated to Turkey at San Stefano; that, by a brilliant stroke, Disraeli transported Indian troops to Cyprus and persuaded Russia to yield to a revision of the Treaty of San Stefano of February 19/March 3, 1878, without resort to arms. It is further common knowledge that Russia was obliged to refer the Turkish situation to a congress called for that purpose at Berlin, where the Treaty of Berlin was negotiated and signed on July 13, 1878 , which so profoundly affected the destinies of the Balkan peninsula. 